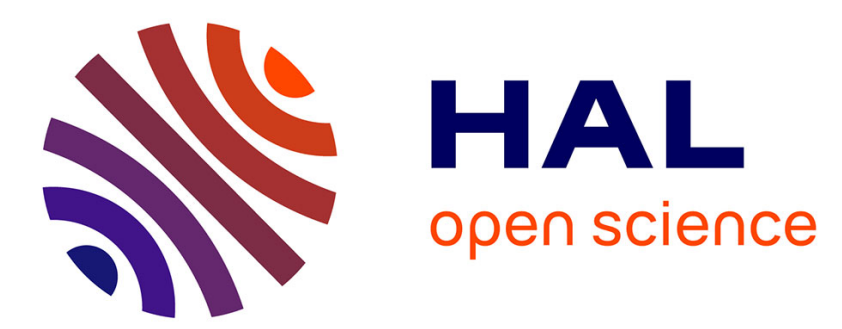

\title{
DEMOCRACY IN THE MUSEUM. THE FOUNDATION AND PERMANENT EXHIBITION OF THE MUSEO ADOLFO SUÁREZ Y LA TRANSICIÓN
}

Jurek Sehrt, Tobias Reckling

\section{- To cite this version:}

Jurek Sehrt, Tobias Reckling. DEMOCRACY IN THE MUSEUM. THE FOUNDATION AND PERMANENT EXHIBITION OF THE MUSEO ADOLFO SUÁREZ Y LA TRANSICIÓN. International Journal of Iberian Studies, 2013, 26:1\&2, pp.103-111. halshs-00843039

\section{HAL Id: halshs-00843039 \\ https://shs.hal.science/halshs-00843039}

Submitted on 10 Jul 2013

HAL is a multi-disciplinary open access archive for the deposit and dissemination of scientific research documents, whether they are published or not. The documents may come from teaching and research institutions in France or abroad, or from public or private research centers.
L'archive ouverte pluridisciplinaire $\mathbf{H A L}$, est destinée au dépôt et à la diffusion de documents scientifiques de niveau recherche, publiés ou non, émanant des établissements d'enseignement et de recherche français ou étrangers, des laboratoires publics ou privés. 


\title{
DEMOCRACY IN THE MUSEUM. THE FOUNDATION AND PERMANENT EXHIBITION OF THE MUSEO ADOLFO SUÁREZ Y LA TRANSICIÓN
}

Jurek Sehrt, Museum of Film and Television in Berlin

E-mail:js@sehrt.de

Tobias Reckling, University of Portsmouth

E-mail: reckling.tobias@gmail.com

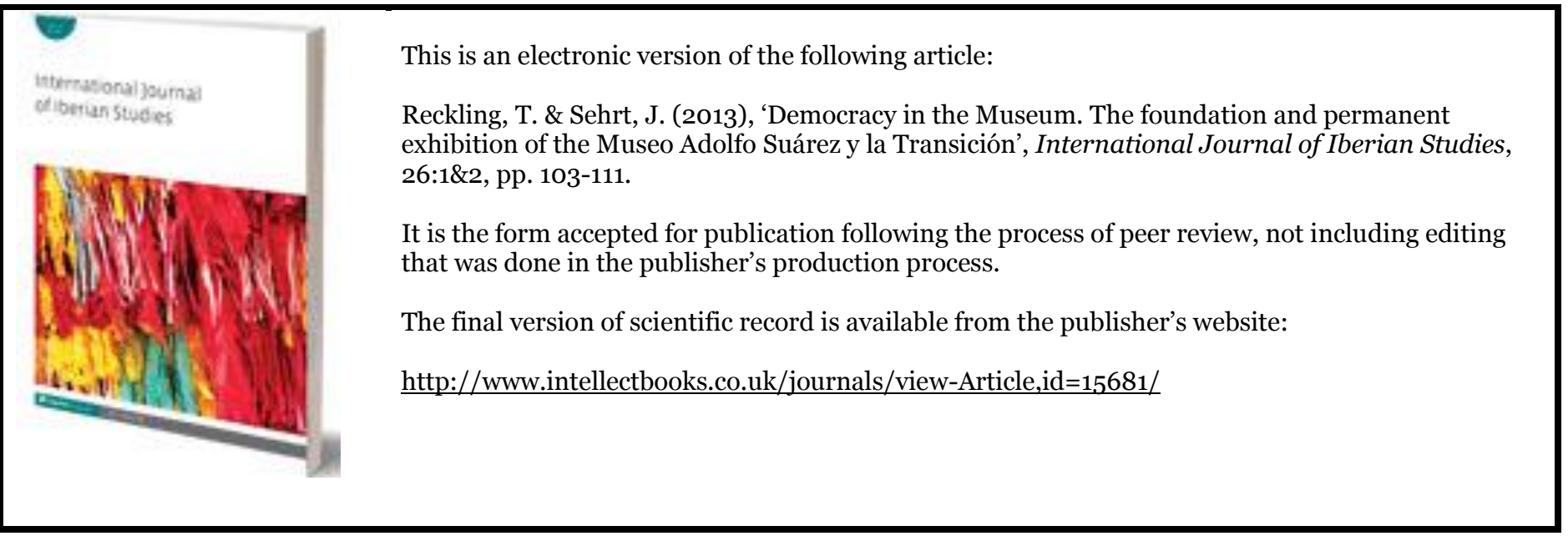

\begin{abstract}
This article examines the recently founded Museo Adolfo Suárez y la Transición - the first Spanish museum dedicated to the Transition to Democracy. Through considering museums as important institutions for the formation of national identities, the article explores the foundation of the museum and its current permanent exhibition in the context of competing narratives of contemporary Spanish history. In doing so, it will be argued that in the context of this museum, the Spanish Transition, as the founding myth for the democratic Spanish nation, also serves to silence the more problematic Spanish history of the twentieth century.
\end{abstract}

Keywords: museum; transition; democracy; identity; Spain; Adolfo Suárez 
$\mathrm{T}$ he Spanish Transition to Democracy is the focal point of ongoing academic and public debates on Spain's national identity. ${ }^{1}$ Balfour and Quiroga (2007: 45), for instance, would 1978, the touchstone of Spanish democracy'. Its actors and central events are commemorated year after year as the origins of the Spanish democracy, while politicians from both the Left and the Right have called for a new 'constitutional patriotism'. At the same time, the Transition and its mythical 'spirit of consensus' have become popular images in political debates and a constant point of reference. However, the memory of the Spanish Transition and its public and political usage are by no means consensual, but highly conflict-laden issues. Most importantly, the still omnipresent criticism of the Transition as a 'pact of silence' (Humlebæk 2010) and demands for greater regional autonomy call for a revision of the results of the Transition (Keating and Wilson 2009).

Against this background, this article will analyse the foundation and the permanent exhibition of the Museo Adolfo Suárez y la Transición (MAST, visited in June 2009, November 2009 and February 2012), which was opened in 2009 in Cebreros, the birthplace of Adolfo Suárez in the region of Castile and León. Museums as sources for the analysis of the construction of national cultures and identities have already received considerable attention (e.g., MacDonald 2006). They are spaces in which competing historical narratives are expressed and collective identities are negotiated. However, in the case of the national identity of democratic Spain, only very few studies have been found. These mainly concentrate on art museums (Holo 1999). This can at least be partly explained by the lack of historical museums at the national level that include the highly contested history of Spain in the twentieth century (Bolaños 2008). Apart from the specialized exhibition of the Museo del Ejército in Toledo, historical museums can only be found in some regions, for instance, Catalonia, where the Museu d'Història de Catalunya was already founded in Barcelona in 1996, and at the local level.

For these reasons, and in the context of the ongoing political debates about Spain's contemporary past, the recent foundation of the MAST marks a surprising development. Although only at a local level, such an institution and the circumstances of its foundation provide insight into the public construction of historical narratives of the Spanish Transition. Methodologically, we draw on recent developments in the field of museum studies and especially the analysis of historical exhibitions. Following the German researcher Joachim Baur (2009), we will separately examine both the politics and the poetics of the MAST and its permanent exhibition. In the first section, we

\footnotetext{
${ }^{1}$ This article is based on a paper presented at the 31st Conference of the Association for Contemporary Iberian Studies, 7-9 September 2010, Rohehampton University, London. The article presents the first results of an ongoing research project on the representation of the Spanish Transition in Spanish museums and exhibitions.
} 
look at the politics, and we will analyse the practical conditions of the creation of the museum and the permanent exhibition. In the second section, which refers to the poetics of the museum, we will examine its actual permanent exhibition. Both sections are based on semi-structured interviews with the founder of the museum (Ángel Luis Alonso, 30 November 2009, Cebreros), the exhibition designer and also one of the curators (Julio Grande, 14 June 2010, e-mail) and the current managing director (Cristina Blanco Sánchez, 30 November 2009 and 2 February 2012, Cebreros), as well as the examination of secondary material such as the yearbooks of the MAST$^{2}$ and newspaper articles.

\section{THE POLITICS OF THE MUSEO ADOLFO SUÁREZ Y LA TRANSICIÓN}

In an interview conducted on 30 November 2009, Ángel Luis Alonso, member of the Popular Party (PP) and Mayor of Cebreros, told us that the approximately 3500 inhabitants of the small community were officially informed about the foundation of the museum in May 2006. However, the question of how to remember Suárez in his birthplace had already caused some debate at the end of the 1980s. As the newspaper Público later reported, an initiative of the then mayor, Pedro Muñoz, member of Suárez' party Centro Democrático y Social (CDS), the renaming of a street after Suárez was opposed by both the PP and the

Partido Socialista Obrero Español (PSOE) (Valmorisco 2008). With the announcement of the foundation of the museum, these conflicts intensified and reached the national level. Alonso and Muñoz, the latter by now an MP for the PSOE in the Congreso de los Diputados in Madrid, were the central opponents of these debates around the question of who had the right to claim the memory of Súarez and the Transition to Democracy.

Discussions about the museum became highly politicized for the first time in May 2007, when Alonso had planned the launch of the museum to be carried out by high-ranking officials of the PPgoverned region. Following a complaint by Muñoz, the electoral committee of Castile and León stopped the event one day before it was supposed to take place: El País, which was also reporting on the issue, wrote that in the face of upcoming elections, the exclusive inauguration of the museum by PP politicians was considered by the electoral committee to be 'contra los principios de objetividad $y$ transparencia del proceso electoral [against the principles of objectivity and transparency of the electoral process]' (Méndez 2007).

\footnotetext{
${ }^{2}$ The yearbooks of the MAST are not printed and are only available on demand in digital form from the museum.
} 
This political criticism of the museum became stronger in the following year after Alonso addressed the Mesa del Congreso de los Diputados in Madrid in order to gain official support for the museum. Muñoz became active again by writing a lengthy letter to the Mesa del Congreso complaining about the politically one-sided nature of the museum as, according to a quotation in an El País article, 'un proyecto ... del PP [a project ... of the PP]' without any kind of participation of the political opposition (Díez 2008). From his point of view, this was directed against the person of Adolfo Suárez and the spirit of political consensus of the Spanish Transition. In 2009, in an interview with the local newspaper El Norte de Castilla, he even claimed that the museum amounted to '... la antitransición. Es que como si Suárez hubiera hecho los Pactos de la Moncloa y luego hubiera llamado a Felipe González, a Carillo o a Fraga a que los firmaran [... the antiTransition. It is as if Suárez had made the Pacts of Moncloa and only afterwards had called upon Felipe González, Carillo or Fraga to sign them]' (Barbadillo 2009). These debates continued, and further interventions by Muñoz and the PSOE also postponed the date of the scheduled opening of the museum for months.

It is not surprising that, against this background, Alonso relied mainly on local and regional institutions to fund the museum. The main part of the overall cost of 2.3 million euros came from the Fundación Asocio de Ávila, which is partly financed by the Spanish state, and further support was received - among others - from the Junta de Castilla y León and the Diputación de Ávila, which were all (and still are) governed at the time by the PP.

The exhibition was actually created over an area of $700 \mathrm{~m}^{2}$ by two specialized firms, SEPINUM and SMA. After the Congreso de los Diputados refused to support the museum, the director of SEPINUM, Julio Grande, recalls that finding original objects became one of the major problems and that the exhibition designers and curators therefore made more use of information boards and reproductions (Julio Grande 14 June 2010, e-mail). In the end, only a limited number of original objects from the Transition period could be obtained through cooperation with - among others the news agency EFE, Radio Television Española (RTVE) and the newspapers $A B C$ and Diario 16 and through private donations. Such objects, for instance, included two chairs used in the Congreso de los Diputados donated by the former president of the Junta de Castilla y León and later PP prime minister José Maria Aznar and the former AP/PP politician Manuel Núñez (Alonso 30 November 2009, interview).

According to Sánchez (interviewed on 2 February 2012), besides being a local museum with a respectable but still limited number of approximately 15,000 visitors in its first year and 25,000 in 2011, the founders consider the MAST of national importance (MAST 2010). This selfunderstanding becomes clear in the ongoing search for partners and cooperation beyond the local 
level. In this context, cooperation with the Universidad Europea de Madrid is of particular importance. This private university has the only chair for the memory of the Transition in Spain. Following the death of its first holder, the former PP politician Rogelio Baón, in 2008 it was renamed the Cátedra Rogelio Baón Memoria de la Transición. It is the central aim of this cooperation to build up a specialized research center on the Spanish Transition in Cebreros, whose documents are supposed to be made available online. Other links were established with the Universitat Internacional de Catalunya, Universidad Católica Santa Teresa de Jesús de Ávila and the Instituto Universitario General Gutiérrez Mellado. More interesting, however, is the cooperation with the rather conservative Asociación para la Defensa de la Transición, which is also connected to the above-mentioned Universidad Europea de Madrid.

At the time of writing it was planned that the museum itself will be incorporated in the newly founded Fundación Transición Democratica in 2012 - with the Real Academia de la Historia as one of its patrons. The by-laws of the foundation have already been accepted by the Diputación de Ávila and are awaiting further approval (Sánchez 2 February 2012, interview).

\section{THE POETICS OF THE PERMANENT EXHIBITION OF THE MUSEO DE ADOLFO SUÁREZ Y LA TRANSICIÓN}

Following the short outline of the foundation of the museum, we will now examine its permanent exhibition. Before entering the actual museum, the attention of the visitors is drawn towards seven busts of the 'fathers of the constitution',3 which surround the building of the renovated church. This assembly of some of the crucial political actors of the Transition sets the tone of the following exhibition. The emphasis of the entire narrative is strongly based on the political elites rather than societal actors, whose importance is increasingly highlighted by researchers (Kaiser and Salm 2009; Radcliff 2011; Threlfall 2008). This perspective on the democratization process was clearly not supported by Alonso, who rejected earlier plans to name the museum the Museo de la Transición y Adolfo Suárez. Instead, by placing the name of Suárez first, Alonso reinforced the notion that Suárez and the King were the central actors responsible for the success of the Transition (Alonso 30 November 2009, interview).

The actual permanent exhibition is organized into five sections: 'La historia del siglo XX hasta la muerte de Franco' ('The history of the 2oth century until the death of Franco'), 'De la

\footnotetext{
${ }^{3}$ Gabriel Cisneros, Miguel Herrero y Rodríguez de Miñón, José Pedro Pérez Llorca, Manuel Fraga Iribarne, Gregorio Peces-Barba, Jordi Solé Tura and Miguel Roca Junyent.
} 
proclamación del Rey hasta las primeras elecciones' ('From the proclamation of the king until the first elections'), 'De las primeras elecciones hasta la proclamación de la Constitución' ('From the first elections to the proclamation of the constitution'), 'De las segundas elecciones hasta la consolidación del processo' ('From the second elections to the consolidation of the process') and 'Suárez, el hombre' ('Suárez, the man') as the last section. Although the first section is called 'The history of the 2oth century until the death of Franco', it mainly consists of texts and objects about the socio-economic development of Spain in the 1960s. The rest of the twentieth century is dealt with quite briefly in a video projection, which was produced by RTVE. This video, which starts the exhibition, is structured into nine chapters and aims to tell the story of Spain from the desastre del 98 until the end of the Spanish Civil War with original images and photographs but without any further comments. Surprisingly, the video does not inform the visitor about neither the creation of Franco's dictatorship nor central events like the exile of Republicans after the Civil War. Instead, the visitor gets the impression of an obvious violent and 'dark' history of Spain in the twentieth century with images from the Semana Trágica in Barcelona in July 1909 and the Spanish Civil War. While this video is merely a prelude, the visitor gets her/his first textual information in a small room dedicated to El desarrollismo de los años 6o. Here, three texts provide information on Spain's economic progress in the 1960s and its tourist and demographic boom; also, the rest of this first part of the exhibition is mainly dedicated to the socio-economic development of Spain during this decade and, in a corner, to the future king Juan Carlos I. However, while information boards are grouped around the walls, the overall attention of the visitor is drawn towards a Seat 600 at the center of this section as the symbol par excellence for this epoch. 4

The main underlying narrative of the Spanish history in the twentieth century therefore transports visitors directly from the collective tragedy of the Spanish Civil War into the 1960s of Franco's Spain. However, while Spanish society in the 1960 s is displayed as being on the brink of democracy, the actual political nature of Franco's regime is hardly discussed. Only two out of eight texts in this first room provide information on the political aspects of the regime. By hardly mentioning the repressive character of the dictatorship, this narrative not only comes close to the so-called 'pact of silence' of the Spanish Transition, but supports the ongoing attempts by the conservative political spectrum to block any discussions about the Civil War and the dictatorship (Balfour and Quiroga 2007: 125). Furthermore, the strong emphasis on the modernizing aspects of Franco's dictatorship is also partly in line with the historical revisionism as formulated by Pío Moa and others on the conservative side of the political spectrum. Since the 1990s, Moa and others have drawn on Francoist historical myths and arguments for their interpretations of the Second

\footnotetext{
${ }^{4}$ The Seat 600 is not only displayed in the MAST, but - for instance - also in the Museu d'Història de Catalunya in Barcelona.
} 
Republic, the Spanish Civil War, Francoism itself and partly also the Transition. 5 In this context, it is a common revisionist argument to highlight socio-economic progress during Franco's regime, while simultaneously downplaying its dictatorial character. Therefore, or so this argument continues, it was economic modernization and the control of social conflict under Franco's dictatorship that prepared Spain for the later Transition to Democracy (Núñez and Stucki 2010; Sevillano Calero 2007).

By stressing the narrative of the modernized society in the 1960s, this first part of the exhibition nevertheless puts strong emphasis on social and economic aspects. The rest of the exhibition, by contrast, concentrates on political events and developments. Information on movements from 'below' can only be found sporadically, for example, in a contemporary newspaper article on demonstrations for a general amnesty later on in the exhibition. Cultural developments are, however, displayed - although only briefly - throughout the entire exhibition. In almost every section the visitor is invited to listen to original music in small cabinets, where the original records are also displayed. For the first room, for instance, the exhibition organizers choose Mi querida España from the singer Cecilia; in the following sections, this is followed by Libertad sin ira from Jarcha (1976) or Habla pueblo habla from Vino Tinto (1976). These audio cabinets remain practically the only reminder of the cultural aspects of the period.

Following this first section, the exhibition continues towards the second part through a 'túnel de la transición' ('tunnel of the Transition'). In this short pathway, the coming of age of Spanish society during the Transition is symbolized by the transformation of a caterpillar into a butterfly and is accompanied by quotations from historians like Javier Tusell and political actors like Alfonso Guerra. At the end of the tunnel and right before entering the second room of the exhibition, an educational diagram explains under the headline 'La elección de un escenario' ('The choice of a scenario') different ideal types of regime change (Transición - ruptura reformista; Continuidad reformismo/inmovilismo; Cambio radical - ruptura/revolución) with a short explanatory quotation from Ángel Sánchez Navarro. At the end of this tunnel, one enters the second room of the exhibition, which narrates central political events like Juan Carlos' first trip to the USA in 1976, the dismissal of Arias Navarro as Prime Minister and the appointment of Suárez, which take us chronologically through the political developments from the installation of the King to the first democratic elections. This strongly text-based narrative is supplemented by rather small original objects like newspaper articles and stamps from the period - a recurring image throughout the exhibition.

\footnotetext{
${ }^{5}$ For a discussion of the literature of historical revisionists about the Spanish Civil War, see the special issue of IJIS, 21 (3), from 2008 on the subject.
} 
The exhibition continues chronologically with a room showing the first elections until the constitutional referendum of 6 December 1978. Starting rather colourfully with reproductions of posters from the electoral campaign in 1977, the visitor enters the single largest room of the entire exhibition. In contrast to the preceding section, here the exhibition makes use of audiovisual and multimedia devices. On computer terminals, information is provided about the key political actors of the Transition, while the original voices of the 'fathers of the constitution' can be listened to on audio stations. While here again political elites are at the center, various information boards are dedicated to the changing state structure and topics like ETA (Euskadi Ta Askatasuna) and terrorism. After showing a reproduction of the constitution at the center of the room, the chronological narrative of the exhibition reaches its end in the last part, which is on the second elections and the consolidation of the democratization process. Besides the information about the new administrative organization of the state, it is not surprising that the failed coup d'etat is at the center of this last part of the exhibition. Through a curtain on which the infamous image of Tejero is printed, the visitor enters a small room dedicated to the events of the 23-F - including the wellknown video of the King's televised speech.

The failed coup d'état marks the end of the Spanish Transition in the historical narrative presented by the MAST. The last text of this section is called 'Hacia el final de la Transición' ('Until the end of Transition'). After a short discussion of the internal break-up of Suárez' party, the Unión del Centro Democrático (UCD) the historical narrative of the Transition ends with the statement that 'España alcanza al fin la madurez democrática [Spain finally reaches democratic maturity]'. Rather surprisingly, the electoral victory of the PSOE under Felipe González in 1982 - often considered by historians as the end of the Spanish Transition - is not mentioned at all in this context. Instead, the Transition to Democracy presented as the 'obra maestra de Adolfo Suaréz [masterpiece of Adolfo Suaréz]' (Alonso 30 November 2009 interview) comes to its closure with the dismantling of the UCD and the foundation of Suárez' own party, the CDS, in 1982. From here, the museum's visitor is transported directly into a room solemnly dedicated to the person of Adolfo Suárez. Below a large biographical chart, and after a display of a group of real-life topographies of Suárez from his childhood until the present day, in this section various original objects like medals and manuscripts of speeches are displayed, which were donated to the museum by Suárez' family. 


\section{CONCLUSION}

The article has analysed the foundation of the Museo Adolfo Suárez y la Transición and its permanent exhibition. Although the museum is only a local institution, it has been shown that both its creation and the historical narrative of its permanent exhibition must be seen, at least partly, in the context of ongoing debates about the historical foundations of Spanish democracy.

The creation of the museum was accompanied by political debates between the PP and the PSOE, which at some points also reached the national level. The arguments brought forward nevertheless fit into the picture of the ongoing debates between the political Left and Right about the memory of the Spanish Transition and its place in the contemporary history of Spain. Furthermore, cooperation with the Universidad Europea de Madrid and the Asociación para la Defensa de la Transición places the museum within current political debates. Following a similar position to that of the PP, the museum strongly opposes any criticism of the Transition, its 'pact of silence' and any revisions of its central text, the constitution. Instead, the Transition is promoted as the unquestionable founding myth of the Spanish democracy. Within this context, the foundation of the museum is indeed highly political.

The analysis of the poetics of the permanent exhibition of the MAST has shown at least partly that the historical narrative of the Spanish Transition presented is displayed as an overall elite-driven success story and is constructed around specific political-ideological assumptions. Specifically, by locating the origins of the Transition to Democracy in the last decade of Franco's dictatorship with few references to the political nature of the regime, the narrative of the exhibition corresponds with the rather conservative right-wing political discourse and the refusal to break with the "pact of silence'. This also applies to the lack of reflection on older democratic traditions like the Second Republic within the historical narrative of the permanent exhibition of the MAST, or, for that matter, the absence of transnational references to other transitions as in Portugal or the importance of external actors like the European Community - references that have become increasingly widespread in contemporary history museums throughout Europe (Kaiser, Krankenhagen and Poehls 2013). Having said that, it is worth noting that more recently the museum has attempted to give a more detailed and balanced picture in temporary exhibitions by introducing subjects such as the publishing house Ruedo ibérico (MAST 2012) and events like $E l$ PCE en la Transición (MAST 2011). 


\section{REFERENCES}

Balfour, S. and Quiroga, A. (2007), The Reinvention of Spain: Nation and Identity since Democracy, Oxford: Oxford University Press.

Barbadillo, I. F. (2009), 'Pedro José Muñoz González: La crisis hace aún más necesario el cambio de poder en Castilla y León', El Norte de Castilla, 13 September 2009, http://www.elnortedecastilla.es/20090913/castilla leon/crisis-hace-necesario-cambio20090913 (Accessed 13 April 2013).

Baur, J. (2009), Die Musealisierung der Migration: Einwanderungsmuseen und die Inszenierung der multikulturellen Nation, Bielefeld: transcript.

Bolaños, M. (2008), Historia de los museos en España, 2nd edn, Gijón: TREA.

Díez, A. (2008), 'División por la figura de Suárez: El PSOE acusa al PP de querer apropiarse del legado del ex presidente', El País, 7 August 2008,

http://elpais.com/diario/2008/o8/o7/espana/1218060006 850215.html (Accessed 13 April 2013).

Holo, S. R. (1999), Beyond the Prado: Museums and Identity in Democratic Spain, Washington, DC: Smithsonian Institute Press.

Humlebæk, C. (2010), 'Party attitudes towards the authoritarian past in Spanish democracy', South European Society and Politics, 15: 3, pp. 413-28.

Kaiser, W., Krankenhagen, S. and Poehls, K. (2014), Exhibiting Europe in Museums. Transnational Networks, Collections, Narratives and Representations, Oxford, New York: Berghahn (forthcoming).

Kaiser, W. and Salm, C. (2009), 'Transition und Europäisierung in Spanien und Portugal. Sozialund christdemokratische Netzwerke im Übergang von der Diktatur zur parlamentarischen Demokratie', Archiv für Sozialgeschichte, 49, pp. 259-82.

Keating, M. and Wilson, A. (2009), 'Renegotiating the state of autonomies: Statute reform and multi-level politics in Spain', West European Politics, 32: 3, pp. 536-58.

Méndez, R. (2007), 'La Junta Electoral prohíbe un acto del PP por apropiarse de la figura de $\begin{array}{llllll}\text { Adolfo Suárez', } & \text { El } & \text { País, } & \text { May } & \text { 2007, }\end{array}$ http://elpais.com/elpais/2007/05/04/actualidad/1178266622_850215.html (Accessed 13 April 2013).

Macdonald, S. (ed.) (2006), A Companion to Museum Studies, Oxford: Blackwell.

MAST (Museo Adolfo Suárez y la Transición). (2010), Anuario 2009, Cebreros.

-—-. (2011), Anuario 2010, Cebreros.

-—-. (2012), Anuario 2011, Cebreros. 
Núñez, X. M. and Stucki, A. (2010), 'Neueste Entwicklungen und Tendenzen der postdiktatoroschen Gischtskultur in Spanien', in S. Troebst (ed.), Postdiktatorische Geschichtskulturen im Süden und im Osten Europas. Bestandsaufnahme und Forschungsperspektiven, Göttingen: Wallstein Verlag, pp. 205-23.

Radcliff, P. (2011), Making Democratic Citizens in Spain: Civil Society and the Popular Origins of the Transición, 1960-78, Basingstoke: Palgrave Macmillan.

Sevillano Calero, F. (2007), 'El revisionismo historiográfico, sobre el pasado reciente en España', Pasado y memoria, 6, pp. 183-90.

Threlfall, M. (2008), 'Reassessing the role of civil society organizations in the Transición to Democracy in Spain', Democratization, 15: 5, pp. 930-51.

Valmorisco, C. (2008), 'Un museo para Suárez ... pero no el título de Hijo Predilecto', Público, 17 August 2008, http://www.publico.es/espana/143248/un-museo-para-suarez-pero-no-eltitulo-de-hijo-predilecto (Accessed 13 April 2013).

\section{CONTRIBUTOR DETAILS}

Tobias Reckling (University of Portsmouth) studied history, political sciences and sociology at the Free University Berlin, the Erasmus University Rotterdam and the Complutense University Madrid. Currently he is working on his Ph.D. at the University of Portsmouth on the international perception of the Spanish Transition.

Contact: Tobias Reckling, Centre for European and International Studies Research (CEISR), University of Portsmouth, Park Building, Room 4.20, King Henry I Street, Portsmouth, PO1 2DZ, United Kingdom.

E-mail: reckling.tobias@gmail.com

Jurek Sehrt (Museum of Film and Television in Berlin) studied history and Spanish at the Free University Berlin, the University of Barcelona and the University of Guadalajara in Mexico. Since 2007, he is the head of the education department in the Museum of Film and Television in Berlin.

Contact: Jurek Sehrt, Institute for Latin American Studies, Department of History, Freie Universität Berlin, Rüdesheimer Str. 54-56, 14197 Berlin, Germany.

E-mail: js@sehrt.de 